\title{
Spillover but no spillback of two invasive parasitic copepods from invasive Pacific oysters (Crassostrea gigas) to native bivalve hosts
}

\author{
M. Anouk Goedknegt - Anne-Karin Schuster • Christian Buschbaum • René Gergs • \\ A. Sarina Jung - Pieternella C. Luttikhuizen - Jaap van der Meer - Karin Troost • \\ K. Mathias Wegner • David W. Thieltges
}

Received: 27 January 2016/ Accepted: 25 September 2016/Published online: 8 October 2016

(C) Springer International Publishing Switzerland 2016

\begin{abstract}
Invasive species can cause indirect effects on native biota by modifying parasite-host interactions and disease occurrence in native species. This study investigated the role of the invasive Pacific oyster (Crassostrea gigas) in potential spillover (co-introduced parasites infect native hosts) and spillback (native or established parasites infect invasive hosts and re-infect native hosts) scenarios of recently introduced (Mytilicola orientalis) and previously established (Mytilicola intestinalis) marine parasitic
\end{abstract}

Electronic supplementary material The online version of this article (doi:10.1007/s10530-016-1285-0) contains supplementary material, which is available to authorized users.

M. A. Goedknegt ( $₫)$ - A.-K. Schuster .

A. S. Jung · P. C. Luttikhuizen · J. van der Meer ·

D. W. Thieltges

Department of Coastal Systems and Utrecht University, NIOZ Royal Netherlands Institute for Sea Research, P.O. Box 59, 1790 AB Den Burg, Texel, The Netherlands e-mail: Anouk.Goedknegt@nioz.nl

A.-K. Schuster · R. Gergs

Institute of Environmental Sciences, University of

Koblenz-Landau, Fortstraße 7, 76829 Landau, Germany

C. Buschbaum · K. M. Wegner

Helmholtz Centre for Polar and Marine Research, Alfred Wegener Institute, Wadden Sea Station Sylt, Hafenstrasse 43, 25992 List/Sylt, Germany

K. Troost

IMARES Wageningen UR, P.O. Box 77,

4400 AB Yerseke, The Netherlands copepods in two regions in northern Europe, the Dutch Delta and the Wadden Sea. By examining 3416 individuals of 11 potential host species from sympatric host populations, we found that the recently introduced parasite $M$. orientalis does not only infect its principal host, the invasive Pacific oyster (prevalence at infected sites $2-43 \%$, mean intensity $4.1 \pm 0.6$ $\mathrm{SE}$ ), but also native blue mussels (Mytilus edulis; 3-63 \%, $2.1 \pm 0.2$ ), common cockles (Cerastoderma edule; $2-13 \%, 1.2 \pm 0.3$ ) and Baltic tellins (Macoma balthica; 6-7\%, $1.0 \pm 0$ ), confirming a spillover effect. Spillback effects were not observed as the previously established $M$. intestinalis was exclusively found in blue mussels (prevalence at infected locations 3-72 \%, mean intensity $2.4 \pm 0.3 \mathrm{SE}$ ). The high frequency of $M$. orientalis spillover, in particular to native mussels, suggests that Pacific oysters may cause strong parasite-mediated indirect impacts on native bivalve populations.

Keywords Mytilicola orientalis $\cdot$ Mytilicola intestinalis · Mytilus edulis · Parasite co-introduction . Invasive species $\cdot$ Wadden Sea

\section{Introduction}

When species are introduced to new ecosystems they often cause a multitude of impacts on native biota (Davis 2009; McGeoch et al. 2010; Lockwood et al. 
2013). Among the commonly identified direct impacts are resource competition with and predation on native species (Parker et al. 1999; Simberloff et al. 2013). However, invasive species can also exert indirect effects, e.g. by modifying native parasite-host interactions that can result in disease emergence in native species. The frequency of such effects is exemplified by the IUCN list of the ' 100 world's worst invasive alien species' (Lowe et al. 2000) which notes diseases as the cause for ecological and economic impacts for a quarter of the invasive species on the list (Hatcher et al. 2012).

Several mechanisms can lead to parasite-mediated effects on native biota (Goedknegt et al. 2016). A first underlying mechanism is the co-introduction of parasites with invasive species which may spill over to naïve native host species (parasite spillover), which can lead to emerging diseases that potentially have knock-on effects on invaded ecosystems (Daszak et al. 2000; Prenter et al. 2004; Kelly et al. 2009). In marine systems this mechanism is relatively common as $73 \%$ of parasite co-introductions with invasive species resulted in parasite spillover from invasive to native species, and almost half of these events led to mass mortalities of native host species (reviewed in Goedknegt et al. 2016).

A second mechanism is that invasive species may modify established parasite-host interactions in the invaded region. For example, when invasive species function as an alternative host for native or previously established parasites, they may increase parasite population sizes and lead to increased infection levels in native host populations (parasite spillback; Kelly et al. 2009). The basic requirements for parasite spillback are that (1) the invasive host species must acquire a native or previously established parasite, (2) the invasive host species must be a competent host and amplify parasite populations, and (3) the parasite must spill back from the invasive to native host species (Kelly et al. 2009). In addition, when these three requirements are met, the relative density of invasive hosts to native hosts must be sufficiently high so that the invasive hosts can act as a reservoir of infection (Paterson et al. 2011, 2013). While there is ample evidence for the acquisition of native parasites by invasive host species (step 1 of parasite spillback; e.g. Miller and Vincent 2006; Georgiev et al. 2014; Sheath et al. 2015; Lewicki et al. 2015), there is little conclusive evidence for an actual amplification and/or spillback to native species (but see Hershberger et al. 2010; Goedknegt et al. 2016). Finally, as an alternative mechanism to parasite spillback, incompetent invasive host species can act as a sink by diluting the native parasite population and thereby reducing the disease risk for native species (transmission interference or parasite dilution; Thieltges et al. 2009; Paterson et al. 2011; Poulin et al. 2011; Goedknegt et al. 2016).

Parasite spillover, spillback and dilution effects may also contribute to indirect impacts of one of the most prominent invaders in European marine ecosystems, the Pacific oyster (Crassostrea gigas). This species originates from East Asia and was imported for commercial cultivation worldwide (Arakawa 1990; Troost 2010), where it often spread from aquaculture facilities into the wild. Pacific oysters were also introduced from British Columbia to the Netherlands (1960s Dutch Delta; 1980s Southern Wadden Sea; Drinkwaard 1999; Troost 2010) and from the UK to Germany (1990s northern Wadden Sea; Reise 1998; Moehler et al. 2011). Currently, both of these genetically differentiated invasions (Moehler et al. 2011) established persistent populations in the Wadden Sea (Ruesink et al. 2005), raising conservation concerns over competition with native blue mussels (Mytilus edulis; Troost 2010). Together with the Pacific oyster, the parasitic copepod Mytilicola orientalis was co-introduced to Europe in the 1960/70 s via oyster imports from cultures in British Columbia (His 1977), where it had been introduced in the 1930s (then still known as Mytilicola ostreae; Wilson 1938). This intestinal parasite has a direct life cycle with a free-living larval stage and was originally described by Mori (1935) from Pacific oysters in its native range in the Sea of Japan. In the Dutch Delta, $M$. orientalis has been observed since the 1990s (Stock 1993), whereas it has only recently been documented in the Wadden Sea (Elsner et al. 2011; Pogoda et al. 2012). The parasite was reported to show relatively low host specificity (Lauckner 1983; Grizel 1985) and has already spilled over to M. edulis and Ostrea edulis at European (French and Dutch) coasts (His 1977; Stock 1993). However, quantitative data on the host range of the introduced parasite in the different invaded regions are largely missing to date. In addition, information on the actual competency of different hosts for M. orientalis is absent. For example, the presence of egg-bearing females would be indicative of competent hosts. Likewise, the body sizes of 
parasites in different host species could be indicative of the relative host competency, with larger parasite body sizes usually related to higher fecundity (Poulin and Morand 1997).

For a closely related congeneric copepod, the previously established Mytilicola intestinalis, more data are available for native hosts in European waters. This species has become notorious as the 'red worm disease' since it allegedly caused mass mortalities of its main host, the blue mussel, in the North Sea in the 1950s and 1960s (Korringa 1968), although there has been considerable debate about the actual lethality of the parasite (e.g. review by Lauckner 1983). M. intestinalis has a smaller geographic range than its congeneric $M$. orientalis and is only found along European coasts where it was first described in Mediterranean mussels (Mytilus galloprovincialis) in the Adriatic Sea (Steuer 1902). Yet, as it has continuously existed in the North Sea for 80 years (first observation in 1937 in Southampton, UK; Cole 1951), this established parasite provides a suitable model system to study spillback effects. Pacific oysters have been mentioned as potential hosts for $M$. intestinalis (Gotto 2004), making spillback via invasive oysters to native host species a likely scenario. Alternatively, if the Pacific oyster appears to be an incompetent host for the parasite $M$. intestinalis, the invasive species potentially acts as a sink, making a dilution effect likely. However, similarly to $M$. orientalis spillover, no quantitative data are available to evaluate the likelihood of such events.

To provide such quantitative data, we investigated the role of the invasive Pacific oyster in potential spillover, spillback and dilution scenarios of the two parasitic copepods (the invasive $M$. orientalis and the previously established $M$. intestinalis) at several sites in two regions in northern Europe with different invasion histories; the Dutch Delta and the Wadden Sea (Fig. 1). By conducting an extensive field survey of sympatric populations of potential hosts, we focused on four specific questions: (1) can the parasitic copepod M. orientalis, which was co-introduced with Pacific oysters, spill over to other native molluscs next to the blue mussel?; (2) are differences in the invasion history of the Pacific oyster between the two regions (Dutch Delta and Wadden Sea) reflected in differences in M. orientalis infection in blue mussels and Pacific oysters in these regions?; (3) do hosts of M. orientalis differ in their suitability for the parasite?; (4) do invasive Pacific oysters become infected with the previously established copepod $M$. intestinalis and thus have the potential to cause spillback to native

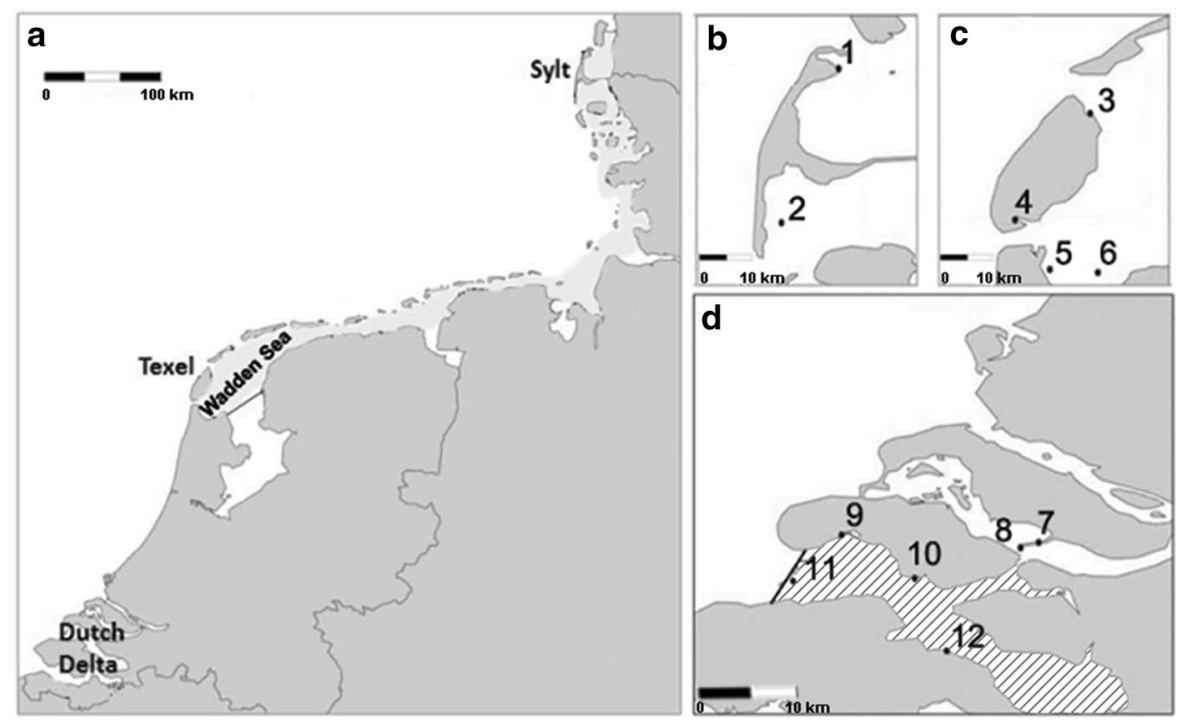

Fig. 1 Sampling locations with sympatric oyster and mussel populations within two regions (Wadden Sea and Dutch Delta) of the main sampling campaign in May 2012 (a), Wadden SeaSylt (b), Wadden Sea-Texel (c) and the Dutch Delta (d). The striped area indicates the Oosterschelde estuary where additional samples were sourced (for more details see Materials and methods and Online Resource 2). Maps adapted from NOAA National Geophysical Data Centre. For exact coordinates of locations see Online Resource 1 
mussel hosts, or does the Pacific oyster act as a potential sink for this parasite? Answering these questions allows for an evaluation of the overall risk of the invasive Pacific oyster to exhibit indirect impacts on invaded ecosystems by mediating parasite-host dynamics.

\section{Materials and methods}

\section{Host sampling}

Host samples originated from three sources: (1) Samples from May 2012 originating from 6 mixed oyster/mussel beds in the Wadden Sea (Fig. 1a-c) and 6 beds in the Dutch Delta (Fig. 1a,d; for coordinates of locations see Online Resource 1). In the first region, we focussed on two islands at both ends of the Wadden Sea to cover both invasion pathways of Pacific oysters (C. gigas): Sylt (north, $\mathrm{n}=2$ locations, Fig. 1a, b) and Texel (south, $\mathrm{n}=4$ locations, Fig. 1a, c). In the Dutch Delta ( $n=6$ locations, Fig. 1a, d), we concentrated on locations around the Oosterschelde estuary, the centre of oyster aquaculture in the Netherlands. At each location in the Wadden Sea and the Dutch Delta, at least 30 Pacific oysters (shell length 53.8-226.5 mm) and blue mussels (M. edulis; $15.5-65.5 \mathrm{~mm}$ ) were collected by hand from mixed oyster/mussel beds. In addition, we collected other mollusc species in the surroundings (up to $500 \mathrm{~m}$ distance) of the mixed beds by sieving excavated sediment (see Table 1 for species list and shell lengths). (2) Due to the low availability of host species other than Pacific oysters and blue mussels in the Dutch Delta, we obtained samples from a monitoring program conducted by the research institute IMARES in this region in May 2012. These samples (mostly common cockles $C$. edule) were used in addition to samples we gathered ourselves from the Dutch Delta. Sampling took place within a grid $(500 \mathrm{~m}$ distance between sampling points) in four areas in the Oosterschelde estuary (Van Zweeden et al. 2012; striped area in Fig. 1; Online Resource 2). At each sampling point, three samples were taken with a cockle shovel (Perdon and Troost 2012). Approximately 100 common cockles $(11.5-46.0 \mathrm{~mm})$ and all other bivalve species in each of the four areas were selected for dissection. (3) To ascertain the presence of previously found M. orientalis in common cockles (Marieke Feis, pers. comm.), two additional sample batches of this host species were taken in summer 2012, one from a tidal flat near an oyster bed in the south of Texel (Mokbaai; Online Resource 3) and one from extensive tidal flats southeast of Texel (Balgzand), the latter being aggregated samples from five transects of $1 \mathrm{~km}$ length each (Dekker and Beukema 2007; Online Resource 4). Host samples were stored in plastic bags for up to 1 week at $4{ }^{\circ} \mathrm{C}$ (known to prevent cross-infections of Mytilicola; Dethlefsen 1972). When longer storage was necessary, samples were frozen for no longer than 3 months at $-20{ }^{\circ} \mathrm{C}$.

\section{Parasite sampling}

Before dissections, we measured the maximum length of each host shell with vernier callipers to the nearest $0.1 \mathrm{~mm}$. Subsequently, the shells were opened and the tissue was first searched for the presence of Mytilicola individuals under a magnification glass (magnification $3-8 \times)$. Following this, the molluscan stomach and intestine were squeezed between two glass slides (to improve visibility of small Mytilicola individuals) and searched again under a stereo microscope (magnification $10-30 \times)$. With these two methods we were able to retrieve larger juveniles $(1.5-2.3 \mathrm{~mm})$ and adults $(>2.3 \mathrm{~mm}$, sexually mature from $2.8 \mathrm{~mm}$ (males) and $4.6 \mathrm{~mm}$ (females)), following Gee and Davey (1986) and Dethlefsen (1985). If present, copepods were carefully removed from the tissue and stored in $95 \%$ denatured ethanol.

\section{Parasite identification}

Species identity of all individuals was morphologically ascertained under a stereo microscope (magnification $10-30 \times$ ) by using the shape of the dorsal appendages as main differential character (pointy in the introduced $M$. orientalis and blunt in the established M. intestinalis; Gotto 2004; Elsner et al. 2011). Since the reliability of morphological identification is currently under investigation (Goedknegt et al., in prep.), subsamples from both parasite species were also molecularly identified with a diagnostic RFLP (restriction fragment length polymorphism) assay developed from taxon specific primers based on Elsner et al. (2011; see Online Resource 5 for details). During the main sampling in May, 921 adult Mytilicola were recovered from Pacific oysters and blue 


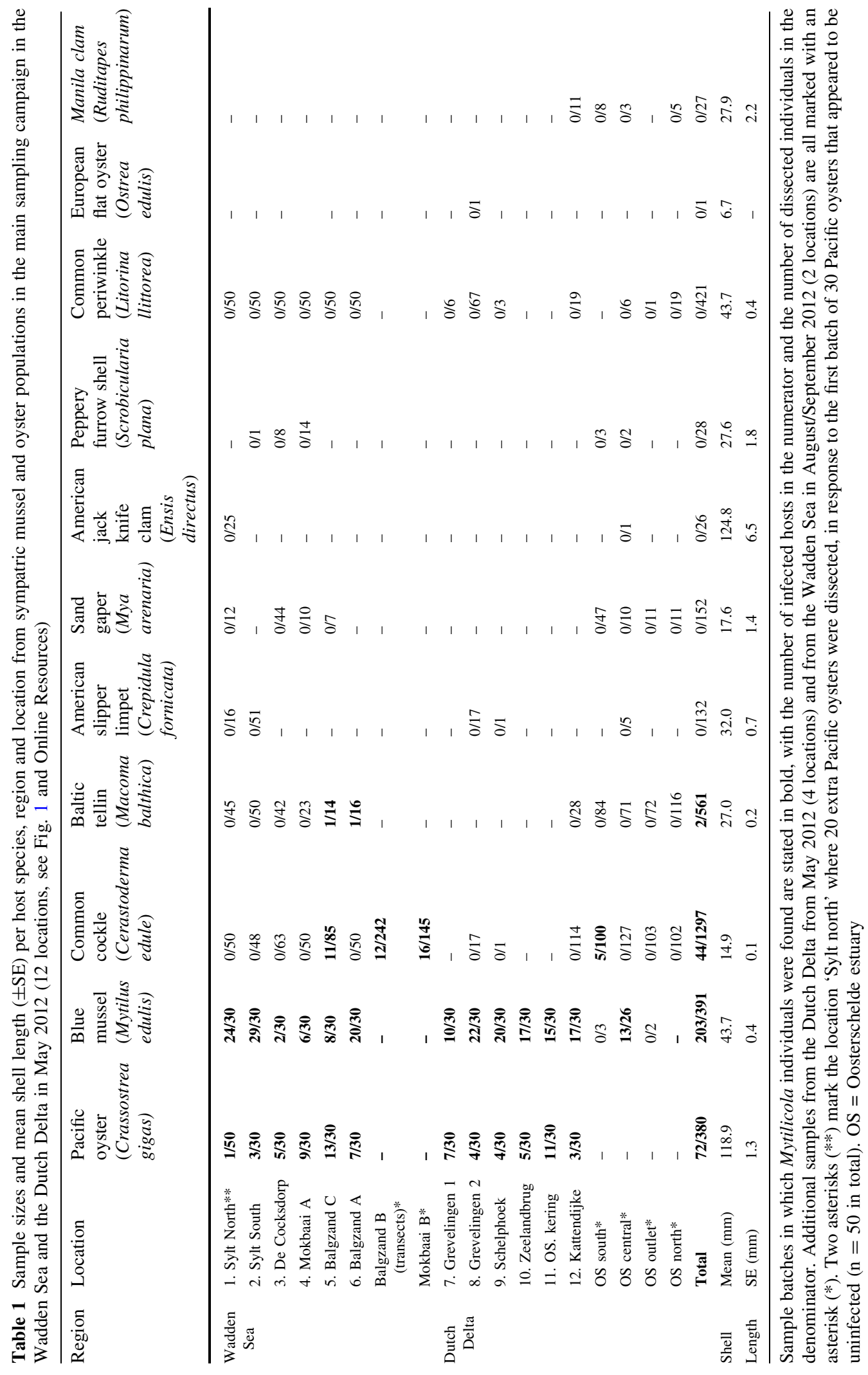


mussels. For oysters and mussels, a subsample of 269 Mytilicola individuals was used for molecular analysis, although for 12 individuals the analysis failed, leaving 257 parasites molecularly identified to species level. More individuals were examined from mussel hosts ( $n=166$, excl. 6 that failed to amplify) than from oyster hosts $(n=91$, excl. 6 that failed to amplify), because blue mussels harboured two morphospecies of Mytilicola and the Pacific oyster only one. The subsamples consisted of randomly picked samples from the Dutch Delta and the Wadden Sea. For the two other host species found to be infected by Mytilicola, we molecularly checked all Mytilicola per host individual (common cockles, $\mathrm{n}=53$, excl. 3 that failed to amplify) and Baltic tellins (Macoma balthica, $\mathrm{n}=2$ ). For all copepods that were molecularly checked for their species identity we also measured their body length. This was done by taking a picture with a camera (AxioCam ICc3) attached to a stereo microscope (Zeiss V8 discovery) and measuring body length with the software package AxioVision.

\section{Statistical analysis}

All statistical analyses were performed using the statistical software package R (R Development Core Team 2015). Model assumptions for all analyses were confirmed using diagnostic model plots (Zuur et al. 2010).

\section{Spillover of M. orientalis}

For all host species that were infected with the recently introduced $M$. orientalis, we calculated the overall prevalence of infection by dividing the total number of infected hosts by the total number of sampled hosts.

\section{Regional differences in M. orientalis infections}

For the 12 sympatric populations of mussels and oysters (main sampling campaign May 2012), we tested whether prevalences and intensities of $M$. orientalis were, relative to the Dutch Delta, on average higher in the Wadden Sea, where the parasite is more recently introduced and where native hosts are still relatively naïve to Mytilicola exposure. We tested this by the use of linear mixed models (LMMs) with a binomial (lme4 package; Bates et al. 2015), and a negative binomial (glmmADMB package; Fournier et al. 2012; Skaug et al. 2014) distribution to model infection prevalence and intensity, respectively. In these models we used region (Wadden Sea or Dutch Delta), host species (blue mussels or Pacific oysters) and the interaction between these factors as fixed factors, and site nested within region as a random factor. For model selection we used backward elimination of non-significant fixed effects that explained little variation.

Additionally, we investigated expected relationships between prevalence and mean intensity of the introduced $M$. orientalis in the invasive Pacific oyster and in the native blue mussel with linear regressions.

Host competency and effect of host shell length on M. orientalis

For all hosts that were infected with the introduced parasitic copepod $M$. orientalis, we used linear models to investigate the relationships between body length of the molecularly identified $M$. orientalis, the sex of the parasite, host species and shell length. A post-hoc Tukey test was applied to test whether parasite body length differs between host species. Additionally, the relationship between the intensity of all (molecular and morphological identification) introduced $M$. orientalis individuals and host shell length was investigated with a GLM with a negative binomial distribution (MASS package, Venables and Ripley 2002).

\section{Spillback of M. intestinalis}

In blue mussels, we tested whether there was a difference in $M$. intestinalis prevalence and intensity between both regions with LMMs with binomial (lme4 package; Bates et al. 2015), and negative binomial distributions (glmmADMB package; Fournier et al. 2012; Skaug et al. 2014), respectively. In these models we used region (Wadden Sea or Dutch Delta) as fixed factor and location nested within region as random factor. Model selection was performed by using backward elimination of non-significant fixed effects that explained little variation.

\section{Results}

Parasite sampling

In total, we investigated 3416 individual hosts from 11 different host species for the presence of both 
Mytilicola species (for sample sizes, numbers of infected individuals and average shell length per species see Table 1). In these 3416 host individuals we found a total of 1020 parasites of both Mytilicola species.

Parasite identification

For all the Mytilicola individuals that could be morphologically (sex and morphospecies) and molecularly identified (307 of the 327 individuals originating from the four principal host species that showed infections, i.e. Pacific oysters (C. gigas), blue mussels (M. edulis), common cockles (C. edule) and Baltic tellins $(M$. balthica), molecular results revealed that $90.0 \%$ of females $(\mathrm{n}=144$ out of 160 females $)$ and $78.9 \%$ of males $(115 / 147)$ were correctly identified to species level with morphological methods.

\section{Spillover of M. orientalis}

The introduced parasite $M$. orientalis (molecularly identified) was found in Pacific oysters (overall prevalence $18.9 \%$ ), blue mussels $(31.3 \%)$, common cockles $(3.3 \%)$ and Baltic tellins $(0.4 \%)$; (for sitespecific infection levels see Table 1). No other mollusc species investigated (Crepidula fornicata, Mya arenaria, Ensis directus, Scrobicularia plana, Littorina littorea, Ostrea edulis, Ruditapes philippinarum) was infected with the invasive copepod.

Differences in $M$. orientalis infections

between host species and regions

While Pacific oysters and blue mussels were infected with the introduced $M$. orientalis at almost all locations, the other two host species were only infected at a limited number of locations in the Wadden Sea: 4 out of 15 locations in common cockles and 2 out of 11 locations in Baltic tellins (Table 1). However, there were probably five infected common cockles in the frozen aggregated samples from the Dutch Delta ('OS south'; prevalence $5 \%$; mean intensity $1 \pm 0$ ), but morphological and molecular identification of the parasites was not possible due to frost damage. The range of prevalences of $M$. orientalis observed over all locations differed among the four host species (Pacific oysters 2-43\%, blue mussels 3-63\%, common cockles 0-13\%, and Baltic tellins 0-7\%) as well as the mean intensities (Pacific oysters; $4.1 \pm 0.6 \mathrm{SE}$, blue mussels; $2.8 \pm 0.2$, common cockles; $1.2 \pm 0.1$ and Baltic tellins; $1.0 \pm 0$ ).

Within the 12 locations with sympatric populations of Pacific oysters and blue mussels, prevalence of $M$. orientalis in Pacific oysters (mean prevalence $\pm \mathrm{SE}$, $19.9 \pm 0.03 \%)$ and blue mussels $(24.0 \pm 0.05 \%)$ did not significantly differ between the two host species (LMM; $\left.\chi^{2}=1.925, P=0.165\right)$, or between the two regions $\left(\chi^{2}=0.045, P=0.832\right.$; Fig. $2 \mathrm{a}$; Table 2$)$. There was also no significant interaction term between host species and region $\left(\chi^{2}=0.022, P=0.883\right.$; mean prevalence oysters: Dutch Delta $18.9 \%$, Wadden Sea $20.9 \%$; mussels Dutch Delta $22.8 \%$, Wadden Sea $25.2 \%$ ). Intensity of $M$. orientalis also did not differ between regions (LMM; $\chi^{2}=0.062, P=0.803$ ), but it differed between host species, being, averaged over the two regions, almost twice as high in Pacific oysters (mean $\pm \mathrm{SE}, 4.1 \pm 0.6$ ) compared to blue mussels (2.4 $\pm 0.3 ; \quad \chi^{2}=21.744, \quad P<0.001 ; \quad$ Fig. $2 b$; Table 2). No significant interaction term between regions and host species was detected $\left(\chi^{2}=0.272\right.$, $P=0.602$; mean intensity \pm SE oysters Dutch Delta $4.0 \pm 0.6$, Wadden Sea $4.2 \pm 1.0$; mussels Dutch Delta $2.0 \pm 0.3$, Wadden Sea $2.2 \pm 0.4$ ).

Furthermore, when investigating the relationship between prevalence and intensity of $M$. orientalis in Pacific oysters and in blue mussels at the 12 sympatric populations (Table 3), we found no significant relationship for prevalence (linear regression; $P=0.868$; Fig. 2a), but a positive relationship for intensity $\left(\mathrm{R}^{2}=0.36 ; d f=10, P<0.05\right.$, Fig. $\left.2 \mathrm{~b}\right)$. In addition, the relationship between prevalence and intensity was significant for mussels (linear regression; $\mathrm{R}^{2}=0.78$; $d f=10, P<0.001$, see Online Resource 6a), but not for oysters ( $P=0.527$, see Online Resource $6 b)$.

Host competency and effect of host shell length on M. orientalis

In general, sexually mature $M$. orientalis females $(>4.6 \mathrm{~mm})$ were found in all four host species, suggesting them to be generally competent hosts for M. orientalis. In the three host species where both parasite sexes were present (Pacific oysters, blue mussels, common cockles), females were always significantly larger than males (linear model $\left.F_{1,194}=485.90, P<0.001\right)$. In addition, there was a significant difference in parasite body size among the 
Fig. 2 a Prevalence of $M$. orientalis in blue mussels (M. edulis) against prevalence of $M$. orientalis in Pacific oysters (C. gigas) and $\mathbf{b}$ mean intensity of $M$. orientalis in blue mussels against the mean intensity of M. orientalis in Pacific oysters. The black line $(y=0.5 x)$ indicates that the intensities in Pacific oysters are about twice as high as in blue mussels. Circles show values for the Dutch Delta, whereas triangles show the values for the Wadden Sea
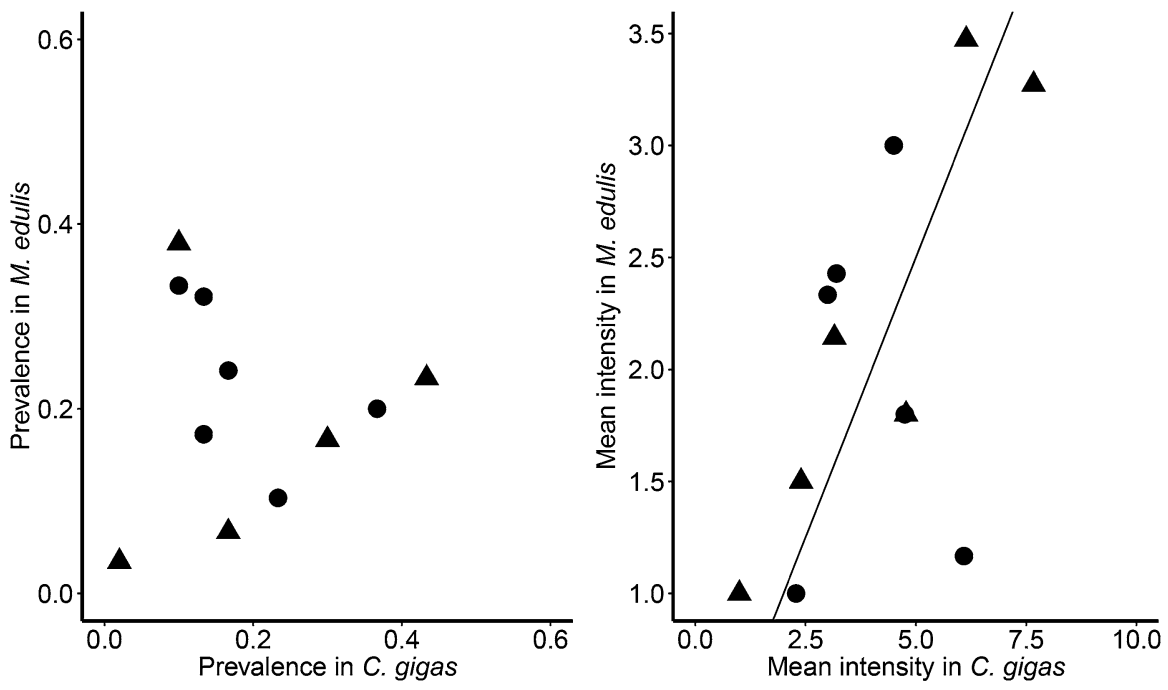

Location $\bullet$ Dutch Delta $\mathbf{A}$ Wadden Sea

Table 2 Results of linear mixed models explaining variation in $M$. orientalis prevalence and intensity in bivalves. Model selection was performed by backwards elimination of non-significant variables and values shown are from the point at which each variable was removed from the model

\begin{tabular}{|c|c|c|c|c|c|}
\hline & Variables & Coefficient & SE & $\chi^{2}$ & $P$ \\
\hline \multicolumn{6}{|l|}{ Prevalence model } \\
\hline \multirow[t]{4}{*}{ Fixed effects } & Intercept & -1.457 & 0.190 & & \\
\hline & Host species & 0.231 & 0.264 & 1.925 & 0.165 \\
\hline & Region & -0.119 & 0.470 & 0.045 & 0.832 \\
\hline & Host species $*$ Region & 0.055 & 0.371 & 0.022 & 0.883 \\
\hline \multirow[t]{3}{*}{ Random effects } & Variables & Variance & SD & & \\
\hline & Intercept & 0.000 & 0.000 & & \\
\hline & Location (nested in Region) & 0.864 & 0.929 & & \\
\hline \multicolumn{6}{|l|}{ Intensity model } \\
\hline \multirow[t]{4}{*}{ Fixed effects } & Intercept & 1.439 & 0.132 & & \\
\hline & Host species & -0.685 & 0.183 & 21.74 & $<0.001$ \\
\hline & Location & -0.004 & 0.216 & 0.062 & 0.803 \\
\hline & Host species $*$ Region & 0.134 & 0.258 & 0.272 & 0.602 \\
\hline \multirow[t]{3}{*}{ Random effects } & Variables & Variance & SD & & \\
\hline & Intercept & 0.012 & 0.109 & & \\
\hline & Location (nested in Region) & 0.067 & 0.258 & & \\
\hline
\end{tabular}

three host species $\left(F_{2,194}=25.34, P<0.001\right)$, with the largest parasites in Pacific oysters, followed by blue mussels and common cockles (Tukey-test; Pacific oysters - common cockles, $P<0.001$; Pacific oysters - blue mussels, $P<0.05$; blue mussels - common cockles, $P<0.001$ ). Only in blue mussels there was a significant relationship between host shell length and body length of $M$. orientalis individuals (linear regression, $\left.\mathrm{R}^{2}=0.86, F_{1,78}=22.67, P<0.001\right)$, but not in the two other host species (Pacific oysters $F_{1,84}=3.18, \quad P=0.078 ; \quad$ common cockles; $F_{1,32}=0.195, P=0.662$; Fig. 3).

Furthermore, the relationship between $M$. orientalis intensity and host shell length differed among host 
Table 3 Prevalences and mean intensities of the parasite M. orientalis in 12 sympatric populations of blue mussels (M. edulis) and Pacific oysters (C. gigas) in May 2012. OS = Oosterschelde estuary

\begin{tabular}{|c|c|c|c|c|c|}
\hline Region & Sampling site & $\begin{array}{l}\text { Prevalence in } \\
\text { oysters }\end{array}$ & $\begin{array}{l}\text { Prevalence } \\
\text { in mussels }\end{array}$ & $\begin{array}{l}\text { Mean intensity } \\
\text { in oysters }\end{array}$ & $\begin{array}{l}\text { Mean intensity } \\
\text { in mussels }\end{array}$ \\
\hline \multirow[t]{6}{*}{ Wadden Sea } & 1. Sylt North & 0.02 & 0.03 & 1.0 & 1.0 \\
\hline & 2. Sylt South & 0.10 & 0.38 & 7.7 & 3.3 \\
\hline & 3. De Cocksdorp & 0.17 & 0.07 & 2.4 & 1.5 \\
\hline & 4. Mokbaai A & 0.30 & 0.17 & 4.8 & 1.8 \\
\hline & 5. Balgzand C & 0.43 & 0.23 & 3.2 & 2.1 \\
\hline & 6. Balgzand A & 0.23 & 0.63 & 6.1 & 3.5 \\
\hline \multirow[t]{6}{*}{ Dutch Delta } & 7. Grevelingen 1 & 0.23 & 0.10 & 2.3 & 1.0 \\
\hline & 8. Grevelingen 2 & 0.13 & 0.32 & 4.5 & 3.0 \\
\hline & 9. Schelphoek & 0.13 & 0.38 & 4.8 & 3.3 \\
\hline & 10. Zeelandbrug & 0.17 & 0.17 & 3.2 & 1.8 \\
\hline & 11. OS. Kering & 0.37 & 0.20 & 6.1 & 1.2 \\
\hline & 12. Kattendijke & 0.10 & 0.33 & 3.0 & 2.3 \\
\hline
\end{tabular}

species. While for blue mussels (GLM; $\mathrm{R}^{2}=0.11$, $\left.\chi^{2}=10.91, \quad P<0.001\right)$ and common cockles $\left(\mathrm{R}^{2}=0.24, \chi^{2}=13.12, P<0.001\right)$ there was a weak but significant positive relationship, it was absent in Pacific oysters $\left(\chi^{2}=0.03, P=0.857\right.$, Fig. 4$)$. The relationships between host shell length and parasite length, and host shell length and parasite intensity were not tested for Baltic tellins because of the small sample size for this species $(\mathrm{n}=2)$.

\section{Spillback of $M$. intestinalis}

Of all investigated potential host species, including Pacific oysters $(\mathrm{n}=380)$, we found only blue mussels to be infected with the previously established copepod M. intestinalis. The parasite was found in both regions in blue mussels $(\mathrm{n}=391)$ with no significant difference in infestation (LLM; $\chi^{2}=1.588, P=0.208$; mean prevalence Dutch Delta: $33.2 \pm 5.9$ SE \%, Wadden Sea: $26.3 \pm 14.1 \%$ ) and no significant difference in intensity (LLM; $\chi^{2}=2.844$, $P=0.092$ ) between the two regions (mean intensity Dutch Delta 2.2 \pm 0.3 SE, Wadden Sea $2.6 \pm 0.6$; Online Resource 7).

\section{Discussion}

Our extensive quantitative assessment of infections of more than 3400 potential hosts showed that the parasitic copepod $M$. orientalis, which was co-introduced with the Pacific oyster ( $C$. gigas), now also infects native blue mussels ( $M$. edulis), common cockles (C. edule) and Baltic tellins (M. balthica) in European waters. Thereby this study adds to a growing amount of literature on parasite spillover from invasive to native species across terrestrial, freshwater and marine ecosystems worldwide (e.g. Warner 1968; Holdich and Reeve 1991; Bauer et al. 2002; Tompkins et al. 2002). M. orientalis has previously been reported to infect native blue mussels and European flat oysters (O. edulis; His 1979; Stock 1993). Unfortunately, our sample size of the European flat oyster was too low to confirm earlier observations of the parasite in this host species.

Our data indicate that blue mussels were infected with the introduced $M$. orientalis at a larger number of locations with much higher infection levels (prevalences and intensities) compared to the other two native host species, common cockles and Baltic tellins. Nevertheless, prevalences found in cockles and tellins should be high enough to sustain a parasite population, because in the native range in Japan, $M$. orientalis has similar prevalences in its native hosts and the local parasite populations are viable (M. Feis, unpublished data). Various reasons can explain the relatively low infection levels of introduced $M$. orientalis in native common cockles and Baltic tellins compared to native blue mussels. First of all, common cockles and Baltic tellins are not always positioned in 

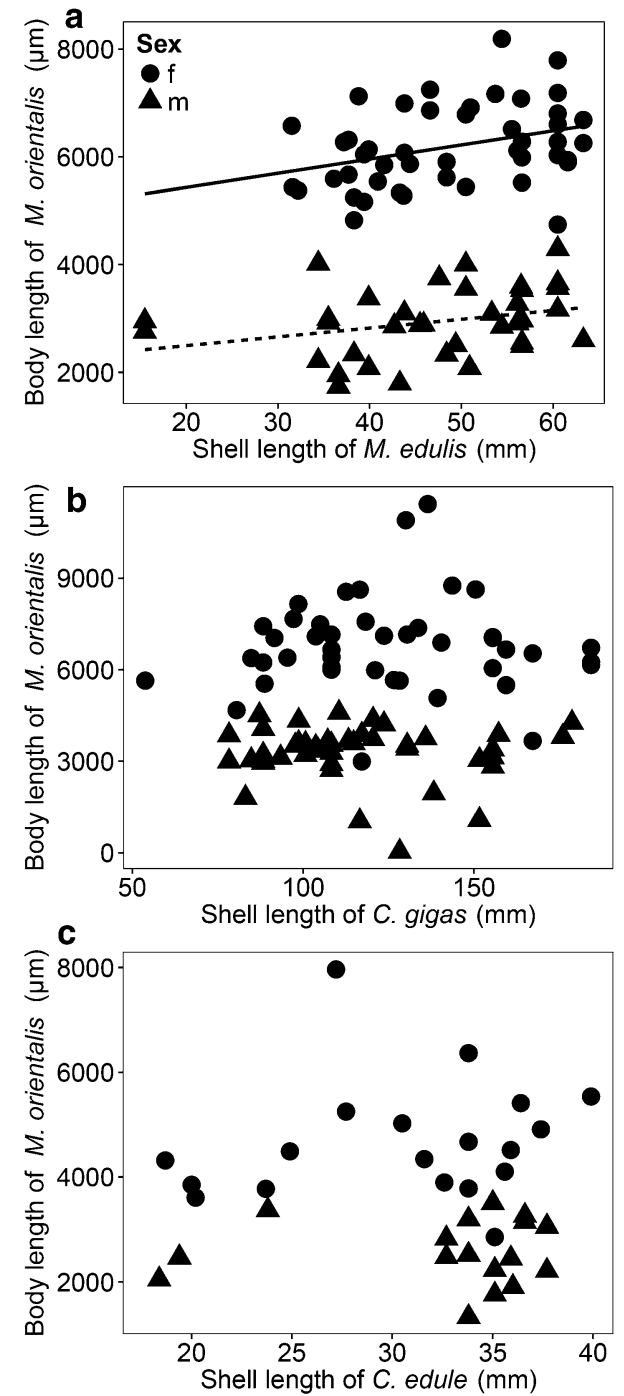

Fig. 3 Relationship between host shell length and body length of molecularly identified $M$. orientalis females and males for a blue mussels $(M$. edulis; females y $=4907.17+26.22 \mathrm{x}$, males y $=2168.34+26.22 \mathrm{x})$, b Pacific oysters $(C$. gigas $)$ and c common cockles (C. edule)

close vicinity of Pacific oysters compared to blue mussels which occupy the same habitat as oysters. Hence, the difference in distance between the source of infection (the Pacific oyster is the principal host of M. orientalis) could explain difference in infection levels between the three native species. However, larval stages of $M$. orientalis have a free-living phase and spend multiple days in the water column (based on M. intestinalis, Gee and Davey 1986; Goedknegt et al. in review), giving them the opportunity to disperse with currents. Consequently, the exposure to free-
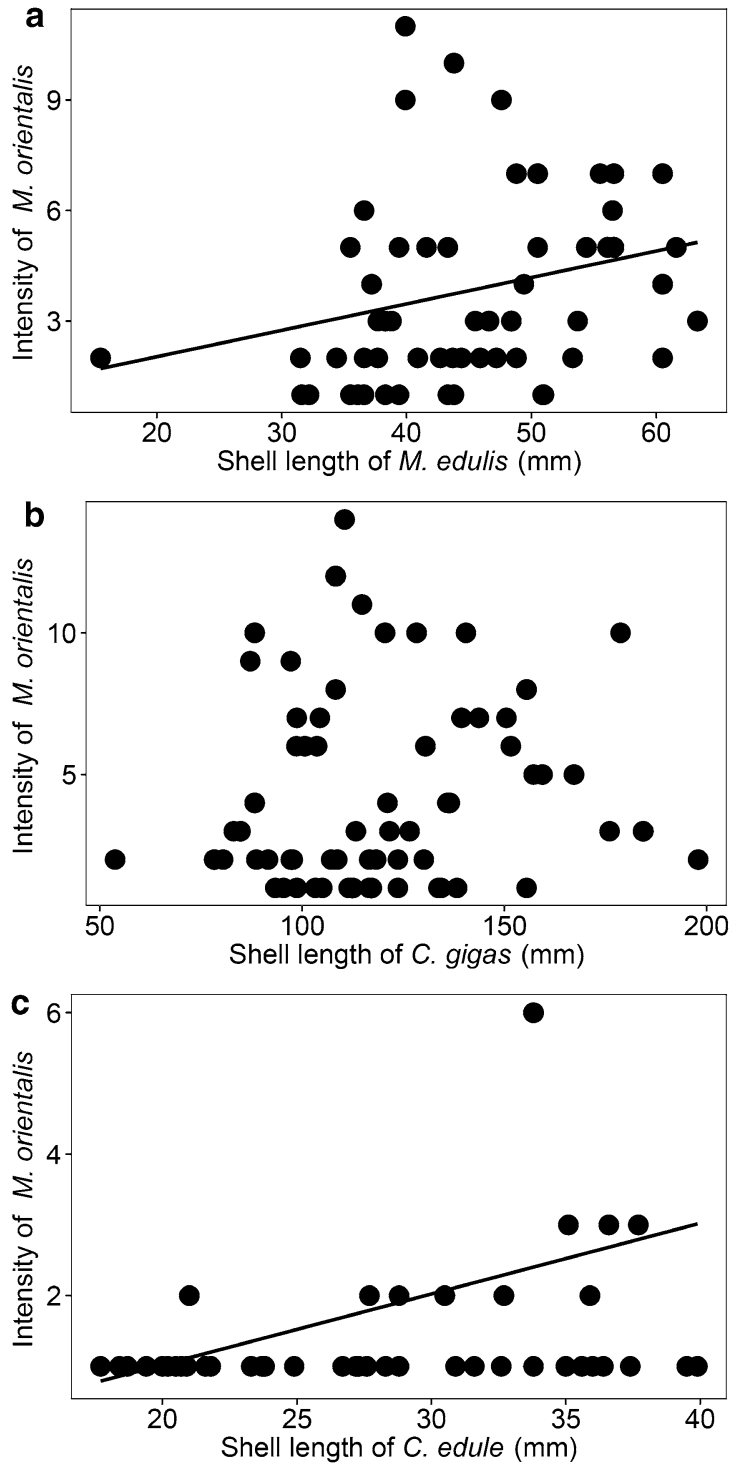

Fig. 4 Relationship between host shell length and $M$. orientalis intensity for a blue mussels (M. edulis; $\mathrm{n}=177$ ), b Pacific oysters (C. gigas; $\mathrm{n}=191$ ), and common cockles (C. edule, $\mathrm{n}=149)$. This analysis includes all morphologically and molecularly identified $M$. orientalis individuals

living infective larvae might actually be similar for the three native host species and therefore the distance from infection source may not be the most plausible explanation for differences in infection levels between the three host species. Second, it could be that oysters and mussels attract larvae of $M$. orientalis from the plankton (e.g. by chemical cues), leading to an accumulation of infections in the main hosts. Thirdly, the endobenthic position and lower filtration rates of 
cockles and tellins (compared to the epibenthic oysters and mussels; reviewed by Troost 2010) may result in lower encounter rates with infective larval stages of $M$. orientalis. This could also be the reason why introduced $M$. orientalis were not found in other potential host species which burrow deep in the sediment such as $M$. arenaria, $S$. plana and E. directus, although for these species sample size may have been too low for strong inference. Fourth, variation in infection levels of $M$. orientalis between the three native host species may be related to host size, with the small size of both species causing space constraint. Indeed, host shell length was a stronger driver of infection levels in common cockles compared to blue mussels. Finally, the difference in infection levels of $M$. orientalis in mussels, cockles and tellins could encompass the relatedness of these three host species to the Pacific oyster. Blue mussels (order: Mytilida) and Pacific oysters (order: Ostreida) both belong to the superorder Pteriomorphia, while common cockles and Baltic tellins both belong to the order Venerida and superorder Heteroconchia (Bouchet et al. 2010). Hence, blue mussels are more closely related to Pacific oysters than the other two host species, possibly explaining differences in host competency and infection levels. However, adult females carrying eggs were observed in all four hosts, suggesting a similar suitability of all host species for reproduction and growth but this remains to be investigated experimentally.

For the two principal hosts, blue mussels and Pacific oysters, the parasite M. orientalis displayed similar geographical distributions with comparable prevalences, but intensities were about twice as high in oysters as in mussels. This is not surprising given the generally smaller body size of blue mussels and their intestines compared to Pacific oysters, resulting in limited space for infections by the intestinal parasites in mussel hosts (mean body size-without egg sacks_of M. orientalis is approximately $4 \mathrm{~mm}$ in males and $10 \mathrm{~mm}$ in females; Grizel 1985). Such a space constraint may also underlie the observation that parasite body size was positively correlated with mussel shell length, while this was not the case for parasites in oysters. However, some care needs to be taken with interpreting these results, as parasites were conserved with different conservation methods which may affect body length measurements (e.g. Thorstad et al. 2007; Goedknegt et al. in prep). In general, mussel size only weakly explained Mytilicola intensity in our data set so that other factors besides size may actually be stronger determinants of infection levels. One of these factors could be host competency which may differ between oysters and mussels. Nonetheless, egg-carrying females were observed both in mussels and oysters and first attempts to hatch eggs and raise copepodid larvae to infective stages originating from egg sacks of $M$. orientalis individuals in blue mussels have been successful, suggesting that blue mussels are a competent host for the parasite (Goedknegt et al. in review). Another potential factor driving infection levels of the invasive copepod may be competition with the previously established $M$. intestinalis. Yet, the relatively few cases of double infections observed were not more or less frequent than expected on a random basis. Therefore, based on this dataset, interspecific competitive exclusion between both parasite species within blue mussels seems to be unlikely. Nevertheless, experimental studies are needed to investigate the detailed modes of interaction between both parasite species.

Our data from 12 sympatric populations of blue mussels and Pacific oysters show that prevalences of the introduced copepod $M$. orientalis did not differ between the two regions within each host species. This suggests that the introduced copepod $M$. orientalis is already well established in the Wadden Sea, although the invasion of Pacific oysters of the Wadden Sea began 10-20 years later than that of the Dutch Delta. However, we observed relatively low infection levels of $M$. orientalis in northern populations of Pacific oysters in the Wadden Sea around the island of Sylt (see also Elsner et al. 2011). Whether this results from a later invasion of this region or differential susceptibility of the genetically distinct northern Pacific oyster populations (Moehler et al. 2011) remains to be investigated. In any case, the 12 sympatric populations showed a strong relationship between infection levels (intensity) in Pacific oysters and blue mussels, suggesting that $M$. orientalis infections in oysters may drive infection levels in mussels. However, mussels could also be an additional source of infection as copepodid stages raised from egg sacks of introduced $M$. orientalis in native blue mussels can experimentally infect conspecifics (Goedknegt et al. in review). The positive relationship between infection intensity of both main host species may also suggest that similar biotic and/or abiotic mechanisms drive infection patterns of both species. However, the 
current dataset is too limited to investigate this further. Field studies investigating infections in both host species, including additional variables as host densities and environmental conditions, as well as controlled experiments will be needed to investigate the drivers of spillover dynamics of the introduced parasite $M$. orientalis.

The risk of parasite spillover may have severe consequences for the new native host species. Although early studies on the impacts of Mytilicola species on, for example, host filtration rates, oxygen consumption and condition index led to controversial results (reviewed by Lauckner 1983), later studies indicated negative effects on host condition (Theisen 1987; Kijewski et al. 2011; Camacho et al. 1997; Feis et al. 2016; Goedknegt et al. in review). Furthermore, both Mytilicola species are known to cause changes in cells of the gut epithelium of both blue mussels ( $M$. intestinalis; Sparks 1962; Moore et al. 1978) and Pacific oysters (M. orientalis; reviewed by Lauckner 1983) that can lead to inflammations of the mucosa and sub-mucosa in the intestines (Watermann et al. 2008). If negative effects of the introduced copepod $M$. orientalis on native blue mussels exist, this may exaggerate the competition between the mussels and the invasive Pacific oysters and may play a role in the complex spatial and temporal population dynamics commonly observed on natural mussel beds (Folmer et al. 2014). Effects of Mytilicola species on common cockles and Baltic tellins have not been studied but seem likely given the fact that the copepods occupy the entire intestine of these relatively small species (observation by A-K. Schuster). However, experimental studies based on controlled infections of hosts are needed to be able to make further inferences about the direct impact of spillover of the introduced $M$. orientalis on native hosts.

While the introduced $M$. orientalis showed spillover to a broad native host range, the previously established $M$. intestinalis was exclusively found in blue mussels. This is in contrast to the literature, where a wide range of mollusc host species has been reported for this copepod species in Europe: M. edulis, M. galloprovincialis, Ruditapes decussatus, Modiolus barbatus, O. edulis, C. gigas, C. edule, Dosinia exoleta, C. fornicata and Venerupis corrugata (Steuer 1902; Hepper 1953; Lauckner 1983; Aguirre-Macedo and Kennedy 1999; Gotto 2004; Dabouineau and Ponsero 2009). However, due to the difficulties of morphological identification of the two species and potential unawareness of investigators of the additional introduction of $M$. orientalis, some of the host species noted in the literature may actually be false positives (Elsner et al. 2011). In our study area, previous studies have only reported the blue mussel, the European flat oyster $O$. edulis and the American slipper limpet $C$. fornicata as hosts for the previously established M. intestinalis (Stock 1965, 1993). The parasite was not found in the latter two host species during our sampling campaign, yet this could also be due to the small sample sizes of these hosts. Nowadays, infections seem to be exclusively restricted to blue mussels, also indicated by two recent studies in the Wadden Sea that found the previously established M. intestinalis only in mussels and not in Pacific oysters (Elsner et al. 2011; Pogoda et al. 2012). Since infections of the invasive Pacific oyster with the previously established $M$. intestinalis are the basic requirement for parasite spillback, our and other data from the literature suggest that the potential for spillback of this parasite species to the native fauna via Pacific oysters is extremely limited.

As a potential incompetent host for M. intestinalis, the Pacific oyster could still attract free-living infective stages and thereby act as a sink for the parasite. Results of experimental infections have shown that it is possible to experimentally infect a Pacific oyster with $M$. intestinalis copepodites, although the infection success was extremely low. In this experimental trial, 25 copepodites were added to each container with one oyster ( $\mathrm{n}=20$ replicates) and after 133 days only one oyster was infected with one $M$. intestinalis parasite, with no remaining copepodites found in the water (M. Feis, unpublished data). This result suggests that the oyster could act as a potential diluter of $M$. intestinalis parasites, thereby reducing disease risk for native blue mussels. Therefore, it would be interesting to examine whether $M$. intestinalis infections in blue mussels have declined after the arrival of the Pacific oyster. Of all the locations investigated, qualitative historical data is only available for the northern German Wadden Sea (Sylt), where M. intestinalis prevalence was $<5 \%$ with a mean intensity of two parasites per infected mussel (Dethlefsen 1972), which is considerably lower than the $69 \%$ prevalence and mean of 3.7 parasites per infected mussel found in our study (after the arrival of the Pacific oyster). This suggests that the Pacific oyster may not play a large 
role in M. intestinalis dilution under natural conditions in the field, but controlled field experiments would help to further clarify this.

Similar to the introduced $M$. orientalis, we observed no difference in prevalence of previously established $M$. intestinalis between the two study regions, the Dutch Delta and the Wadden Sea. Hence, $M$. intestinalis seems to be well established in both regions. However, $M$. intestinalis intensity was slightly higher in the Wadden Sea. This resulted from the particularly high prevalences in blue mussels around the island of Sylt found in this study (69-72 \%), that were also previously reported from the northern Wadden Sea (Thieltges et al. 2006; Elsner et al. 2011), while sites from the inner German Bight show intermediate infection levels (prevalence about $25 \%$; Pogoda et al. 2012). For the Texel region, previous data are, unfortunately, missing (Drinkwaard 1999) but our data tentatively suggest a north-south infection gradient of $M$. intestinalis in the Wadden Sea.

In this study, species identification of both Mytilicola species was based on morphological and (partial) molecular identification, the latter revealing an accuracy in morphological identification of $90.0 \%$ for females and $78.9 \%$ for males. Although morphological identification does not seem to be $100 \%$ reliable, these inaccuracies do not affect our general conclusions due to the following: (1) all $M$. orientalis individuals from newly discovered hosts (Baltic tellins and common cockles) were molecularly identified, so that we could ascertain spillover from Pacific oysters; and (2) from the 91 Mytilicola individuals from Pacific oysters that were molecularly identified, none appeared to be the previously established $M$. intestinalis, which confirms low or no risk of parasite spillback mediated by the Pacific oyster. The exact prevalences and intensities of both Mytilicola species in blue mussels and Pacific oysters would probably slightly differ if all Mytilicola individuals had been identified with molecular methods. However, as these minor differences appeared to be unbiased, they are unlikely to affect the validity of the results obtained here.

In conclusion, our study revealed widespread spillover of M. orientalis, which was co-introduced with Pacific oysters, to native common cockles and Baltic tellins in addition to blue mussels, from which spillover was already reported (Elsner et al. 2011;
Pogoda et al. 2012). Second, our study showed that M. orientalis infections in Pacific oysters and blue mussels do not differ between the two study regions (the Dutch Delta and the Wadden Sea) despite their different invasion histories. However, within the Wadden Sea region there was a gradient with higher infection levels in the south (Texel) than in the north (Sylt), probably reflecting the ongoing invasion process from south to north. Finally, we showed that the risk for spillback of the previously established $M$. intestinalis via infections of Pacific oysters is very low as this copepod was absent from oysters. In contrast, the Pacific oyster may rather act as sink for the parasite, thereby reducing disease risk for native blue mussels. However, our data from sites with high prevalence of $M$. intestinalis infections suggest that dilution by invasive Pacific oysters might be a comparatively small effect for overall parasite population growth. The high occurrence of parasite spillover suggests that Pacific oysters may have strong indirect impacts on native ecosystems and future studies will be needed to investigate the effects of the introduced $M$. orientalis infections on native hosts. In addition, the exact biotic and abiotic drivers behind the spillover of $M$. orientalis from Pacific oysters to native hosts are thus far unknown and this remains a topic for future studies. To investigate these mechanisms on larger temporal and spatial scales, more extensive datasets are required that need to be analysed in an individual-based modelling framework (e.g. Wells 2015). Studying dynamics, drivers and effects of spillover of co-introduced parasites like $M$. orientalis will improve our understanding of the overall direct and indirect effects of invasive species, such as the Pacific oyster, in ecosystems worldwide.

Acknowledgments We thank the Netherlands Organization for Scientific Research (NWO) and the German Bun desministerium für Bildung und Forschung (BMBF) for funding (bilateral NWO-ZKO project 839.11.002). AnneKarin Schuster thanks the German Academic Exchange Service (DAAD) for financial support. We are grateful to Anneke Bol for help with the molecular analysis and Rob Dekker, Jarco Havermans, Reinier Nauta, Simone Muck and Jennifer Welsh for their support with field work and Carola van Zweeden and Ad van Gool for the provision of samples. We also thank Karsten Reise for his fruitful comments that improved the manuscript. Finally, we appreciate the feedback of the three anonymous reviewers that helped to improve the manuscript. 


\section{References}

Aguirre-Macedo ML, Kennedy CR (1999) Diversity of metazoan parasites of the introduced oyster species Crassostrea gigas in the Exe Estuary. J Mar Biol Assoc UK 79:57-63

Arakawa KY (1990) Commercially important species of oysters in the world. Mar Freshw Behav Phy 17:1-13

Bates D, Maechler M, Bolker B, Walker S (2015) Fitting linear mixed-effects models using lme4. J Stat Soft 67:1-48

Bauer ON, Pugachev ON, Voronin VN (2002) Study of parasites and diseases of sturgeons in Russia: a review. J Appl Ichthyol 18:420-429

Bouchet P, Rocroi J-P, Bieler R, Carter JG, Coan EV (2010) Nomenclator of bivalve families with a classification of bivalve families. Part 1. Nomenclator of bivalve names of the family-group and above. Part 2. Classification of bivalve families. Malacologia 52:1-184

Camacho AP, Villalba A, Labarta U, Beiras R (1997) Absorption efficiency and condition of cultured mussels (Mytilus edulis galloprovincialis Linnaeus) of Galicia (NW Spain) infected by parasites Marteilia refringens Grizel et al. and Mytilicola intestinalis Steuer. J Shellf Res 16:77-82

Cole HA (1951) Le Mytilicola en Angleterre. Rev des Trav (de l'Office Sci et Tech Des Peches Marit) 17:9-13

Dabouineau L, Ponsero A (2009) Synthesis on biology of common European cockle Cerastoderma edule, 2nd edn. Université Catholique de l'Ouest - Réserve Naturelle Nationale Baie de St-Brieuc, p 17

Daszak P, Cunningham AA, Hyatt AD (2000) Emerging infectious diseases of wildlife-threats to biodiversity and human health. Science 287:443-449

Davis MA (2009) Invasion biology. Oxford University Press, Oxford

Dekker R, Beukema JJ (2007) Long-term and large-scale variability in productivity of the tellinid bivalve Macoma balthica on Wadden Sea tidal flats. Mar Ecol Prog Ser 337:117-134

Dethlefsen V (1972) Zur Parasitologie der Miesmuschel (Mytilus edulis L., 1758). Ber der Dtsch Wiss Komm Meeresforsch 22:344-371

Dethlefsen V (1985) Mytilicola intestinalis parasitism. In: Sindermann CJ (ed) Fiches d'identification des maladies et parasites des poissons, crustacés et mollusques, vol 24. ICES, Copenhagen, pp 1-4

Drinkwaard AC (1999) Introductions and developments of oysters in the North Sea area: a review. Helgol Meeresunters 52:301-308

Elsner NO, Jacobsen S, Thieltges DW, Reise K (2011) Alien parasitic copepods in mussels and oysters of the Wadden Sea. Helgol Mar Res 65:299-307

Feis ME, Goedknegt MA, Thieltges DW, Buschbaum C, Wegner KM (2016) Biological invasions and host-parasite coevolution: different coevolutionary trajectories along separate parasite invasion fronts. Zoology 119:366-374

Folmer EO, Drent J, Troost K, Büttger H, Dankers N, Jansen J, van Stralen M, Millat G, Herlyn M, Philippart CJM (2014) Large-scale spatial dynamics of intertidal mussel (Mytilus edulis L.) bed coverage in the German and Dutch Wadden Sea. Ecosystems 3:550-566

Fournier DA, Skaug HJ, Ancheta J, Ianelli J, Magnusson A, Maunder M, Nielsen A, Sibert J (2012) AD Model Builder: using automatic differentiation for statistical inference of highly parameterized complex nonlinear models. Optim Methods Softw 27:233-249

Gee JM, Davey JT (1986) Stages in the life history of Mytilicola intestinalis STEUER, a copepod parasite of Mytilus edulis (L.), and the effect of temperature on their rates of development. ICES J Mar Sci 42:254-264

Georgiev BB, Anglov A, Vasileva GP, Sánchez MI, Hortas F, Mutafchiev Y, Pankov P, Green AJ (2014) Larval helminths in the invasive American brine shrimp Artemia franciscana throughout its annual cycle. Acta Parasitol 59:380-389

Goedknegt MA, Feis ME, Wegner KM, Luttikhuizen PC, Buschbaum C, Camphuysen KC, van der Meer J, Thieltges DW (2016) Parasites and marine invasions: ecological and evolutionary perspectives. J Sea Res 113:11-27

Gotto V (2004) Commensal and parasitic copepods associated with marine invertebrates. In: Synopses of the British Fauna (new series) no. 46, 2nd edn, Linnean Society of London and the Estuarine and Coastal Sciences Association by Field Studies Council, Shrewsbury

Grizel H (1985) Parasitose a Mytilicola orientalis Mori. In: Sindermann DJ (ed) Fiches d'identification des maladies et parasites des poissons, crustacés et mollusques, vol 24. ICES, Copenhagen, pp 1-4

Hatcher MJ, Dick JTA, Dunn AM, Perkins S (2012) Disease emergence and invasions. Funct Ecol 26:1275-1287

Hepper BT (1953) Artificial infection of various molluscs with Mytilicola intestinalis, Steuer. Nature 172:250

Hershberger PK, van der Leeuw BK, Gregg JL, Grady CA, Lujan KM, Gutenberger SK, Purcell MK, Woodson JC, Winton JR, Parsley MJ (2010) Amplification and transport of an endemic fish disease by an introduced species. Biol Invasions 12:3665-3675

His E (1977) Observations préliminaires sur la présence de Mytilicola orientalis Mori (1935) chez Crassostrea gigas Thunberg dans le basin d'Arcachon. Bull Soc Géol amis Mus Havre 64:7-8

His E (1979) Mytilicolides et myicolides parasites des lamellibranches d'interet commercial du bassin d'Arcachon. Haliotis 8:99-102

Holdich DM, Reeve ID (1991) Distribution of freshwater crayfish in the British Isles, with particular reference to crayfish plague, alien introductions and water quality. Aquat Conserv Mar Freshw Ecosyst 1:139-158

Kelly DW, Paterson RA, Townsend CR, Poulin R, Tompkins DM (2009) Parasite spillback: a neglected concept in invasion ecology? Ecology 90:2047-2056

Kijewski T, Śmietanka B, Zbawicka M, Gosling E, Hummel H, Wenne R (2011) Distribution of Mytilus taxa in European coastal areas as inferred from molecular markers. J Sea Res 65:224-234

Korringa P (1968) On the ecology and distribution of the parasitic copepod Mytilicola intestinalis Steuer. Bijdr Dierkd 38:47-57

Lauckner G (1983) Diseases of mollusca: Bivalvia. In: Kinne O (ed) Diseases of marine animals. Biologische Anstalt Helgoland, Hamburg, pp 477-1083

Lewicki KE, Huyvaert KP, Piaggio AJ, Diller LW, Franklin AB (2015) Effects of barred owl (Strix varia) range expansion on Haemoproteus parasite assemblage dynamics and 
transmission in barred and northern spotted owls (Strix occidentalis caurina). Biol Invasions 17:1713-1727

Lockwood JL, Hoopes MF, Marchetti MP (2013) Invasion ecology. Wiley-Blackwell, West Sussex

Lowe S, Browne M, Boudjelas S, De Poorter M (2000) 100 of the world's worst invasive alien species: a selection from the global invasive species database. Invasive Species Specialist Group, Auckland

McGeoch MA, Butchart SHM, Spear D, Marais E, Kleynhans EJ, Symes A, Chanson J, Hoffmann M (2010) Global indicators of biological invasion: species numbers, biodiversity impact and policy responses. Divers Distrib 16:95-108

Miller A, Vincent RE (2006) Rapid natural selection for resistance to an introduced parasite of rainbow trout. Evol Appl $1: 336-341$

Moehler J, Wegner KM, Reise K, Jacobsen S (2011) Invasion genetics of Pacific oyster Crassostrea gigas shaped by aquaculture stocking practices. J Sea Res 66:256-262

Moore MN, Lowe DM, Gee JM (1978) Histopathological effects induced in Mytilus edulis by Mytilicola intestinalis and the histochemistry of the copepod intestinal cells. J Cons Int Explor Mer 38:6-11

Mori T (1935) Mytilicola orientalis, a new species of parasitic Copepoda. Zool Soc Jpn 47:687-693

Parker IM, Simberloff D, Lonsdale D, Goodel K et al (1999) Impact: toward a framework for understanding the ecological effects of invaders. Biol Invasions 1:3-19

Paterson RA, Townsend CR, Poulin R, Tompkins DM (2011) Introduced brown trout alternative acanthocephalan infections in native fish. J Anim Ecol 80:990-998

Paterson RA, Lal A, Dale M, Townsend CR, Poulin R, Tompkins DM (2013) Relative competence of native and exotic fish hosts for two generalist native trematodes. Int J Parasitol: Parasites Wildl 2:136-143

Perdon J, Troost K (2012) Handboek monstertuigen schelpdier inventarisaties. CVO: 12.006, IMARES, Yerseke

Pogoda B, Jungblut S, Buck BH, Hagen W (2012) Infestation of oysters and mussels by mytilicolid copepods: differences between natural coastal habitats and two offshore cultivation sites in the German Bight. J Appl Ichtyol 28:756-765

Poulin R, Morand S (1997) Parasite body size distributions: interpreting patterns of skewness. Int $\mathrm{J}$ Parasitol 27:959-964

Poulin R, Paterson RA, Townsend CR, Tompkins DM, Kelly DW (2011) Biological invasions and the dynamics of endemic diseases in freshwater ecosystems. Freshw Biol 56:676-688

Prenter J, MacNeil C, Dick JT, Dunn AM (2004) Roles of parasites in animal invasions. Trends Ecol Evol 19:385-390

R Development Core Team (2015) R: A language and environment for statistical computing. R Foundation for Statistical Computing, Vienna, Austria. https://www.R-project.org/

Reise K (1998) Pacific oysters invade mussel beds in the European Wadden Sea. Senckenberg Marit 28:167-175

Ruesink JL, Lenihan HS, Trimble AC, Heiman KW, Micheli F, Byers JE, Kay MC (2005) Introduction of non-native oysters: ecosystem effects and restoration implications. Annu Rev Ecol Evol Syst 36:643-689

Sheath DJ, Williams CF, Reading AJ, Britton JR (2015) Parasites of non-native freshwater fishes introduced to England and Wales suggest enemy release and parasite acquisition. Biol Invasions 17:2235-2246

Simberloff D, Martin J, Genovesi P et al (2013) Impacts of biological invasions: what's what and the way forward. Trends Ecol Evol 25:58-66

Skaug H, Fournier D, Bolker B, Magnusson A, Nielsen A (2014) Generalized linear mixed models using AD Model Builder. $\mathrm{R}$ package version 0.8 .0

Sparks AK (1962) Metaplasia of the gut of the oyster Crassostrea gigas (Thunberg) caused by infection with the copepod Mytilicola orientalis Mori. J Invert Pathol 4:57-62

Steuer A (1902) Mytilicola intestinalis n. gen. n. spec. aus dem Darme von Mytilus galloprovincialis Lam. (Vorläufige Mittheilung). Lam Zool Anz 25:635-637

Stock JH (1965) On copepoda associated with Dutch molluscs. Basteria 29:65-71

Stock JH (1993) Copepoda (Crustacea) associated with commercial and non-commercial Bivalvia in the East Scheldt, The Netherlands. Bijdr Dierk 63:61-64

Theisen BF (1987) Mytilicola intestinalis Steuer and the condition of its host Mytilus edulis L. Ophelia 27:77-86

Thieltges DW, Krakau M, Andresen H, Fottner S, Reise K (2006) Macroparasite community in molluscs of a tidal basin in the Wadden Sea. Helgol Mar Res 60:307-316

Thieltges DW, Reise K, Prinz K, Jensen KT (2009) Invaders interfere with native parasite-host interactions. Biol Invasions 11:1421-1429

Thorstad EB, Finstad AG, Jensen AJ (2007) To what extent does ethanol and freezing preservation cause shrinkage of juvenile Atlantic salmon and European minnow? Fish Manag Ecol 14:295-298

Tompkins DM, Sainsbury AW, Nettleton P, Buxton D, Gurnell J (2002) Parapoxvirus causes a deleterious disease in red squirrels associated with UK population declines. Proc R Soc B 269:529-533

Troost K (2010) Causes and effects of a highly successful marine invasion: case-study of the introduced Pacific oyster Crassostrea gigas in continental NW European estuaries. J Sea Res 64:145-165

Van Zweeden C, Troost K, van Asch M, Kesteloo-Hendrikse JJ (2012) Het kokkelbestand in de Nederlandse kustwateren in 2012. IMARES Wageningen Report, C094/12. IMARES Wageningen UR, Ijmuiden, $45 \mathrm{pp}$

Venables WN, Ripley BD (2002) Modern applied statistics with $\mathrm{S}$, 4th edn. Springer, New York

Warner RE (1968) Role of introduced diseases in extinction of endemic Hawaiian avifauna. Condor 70:101-120

Watermann B, Thomsen A, Kolodzey H, Daehne B, Meemken M, Pijanowska U, Liebezeit G (2008) Histopathological lesions of molluscs in the harbour of Norderney, Lower Saxony, North Sea (Germany). Helgol Mar Res 62:167-175

Wells K (2015) The importance of parasite geography and spillover effects for global patterns of host-parasite associations in two invasive species. Divers Distrib 21:477-486

Wilson CB (1938) A new copepod from Japanese oysters transplanted to the Pacific Coast of the United States. J Wash Acad Sci 28:284-288

Zuur AF, Ieno EN, Elphick CS (2010) A protocol for data exploration to avoid common statistical problems. Methods Ecol Evol 1:3-14 